This work is licensed under a Creative Commons Attribution 3.0 License.

\author{
Research article
}

\title{
A new species of Anadia (Reptilia, Squamata) from the Venezuelan 'Lost World', northern South America
}

Kok P.J.R. \& Rivas G.A. 2011. A new species of Anadia (Reptilia, Squamata) from the Venezuelan 'Lost World', northern South America. European Journal of Taxonomy 3: 1-18. http://dx.doi.org/10.5852/ejt.2011.3

\section{Philippe J.R. KOK ${ }^{1,2,4}$ \& Gilson A. RIVAS ${ }^{3}$}

${ }^{1}$ Biology Department, Unit of Ecology and Systematics, Vrije Universiteit Brussel, 2 Pleinlaan, B-1050 Brussels, Belgium

${ }^{2}$ Department of Vertebrates, Royal Belgian Institute of Natural Sciences, 29 rue Vautier, B-1000 Brussels, Belgium

${ }^{3}$ Museo de Biologia, Facultad Experimental de Ciencias, La Universidad del Zulia, Apartado Postal 526, Maracaibo 4011, Maracaibo, Venezuela

4Email: Philippe.Kok@vub.ac.be, Philippe.Kok@naturalsciences.be

\begin{abstract}
A new gymnophthalmid lizard of the genus Anadia Gray, 1845 is described from the summit of Abakapá-tepui, Bolívar State, Venezuela, between 2200-2242 m elevation. The new species, Anadia mcdiarmidi sp. nov., is endemic to the Chimantá Massif and seemingly also occurs on Amurí-tepui and Murei-tepui. The new taxon is mainly distinguished from all known congeners by the following combination of characters: body fairly robust, dorsal scales small and quadrangular, middorsal scales 53-57, suboculars large, subequal in size, with sometimes one scale slightly protruding downward between $4^{\text {th }}$ and $5^{\text {th }}$ supralabial, nasal entire, without sub-nostril groove, body uniform beige or greyish to bluish brown in life, devoid of any conspicuous pattern in males, venter immaculate golden grey in life, femoral pores 9-10 on each side in males, preanal pores absent, hemipenis globose, weakly bilobed, bordered by numerous flounces $(>20)$ bearing comblike rows of minute weakly mineralized spinules. The presence of a species of Anadia, a primarily Andean genus, on the top of tepuis is of considerable interest to the understanding of the Pantepui biogeography.
\end{abstract}

Key words. Gymnophthalmidae, Lizard, Hemipenes, Chimantá Massif, Pantepui.

\section{Introduction}

Gymnophthalmid lizards of the genus Anadia Gray, 1845 may be gracile, narrow-headed and semiarboreal or mostly terrestrial, more robust with a broader head (Oftedal 1974). This genus is primarily Andean, with 17 currently recognized species distributed in the Ecuadorian Andes (A. petersi Oftedal, 1974), Colombian Andes [A. altaserrania Harris \& Ayala, 1987; A. bogotensis (Peters, 1863); A. pulchella Ruthven, 1926], Venezuelan Andes [A. bitaeniata Boulenger, 1903; A. brevifrontalis (Boulenger, 1903); A. hobarti La Marca \& García-Pérez, 1990; A. pamplonensis Dunn, 1944], the central coastal range in Venezuela [A. marmorata (Gray, 1846); A. steyeri Nieden, 1914], the eastern coastal range in Venezuela (A. blakei Schmidt, 1932; A. pariaensis Rivas, La Marca \& Oliveros, 1999), and at lower elevations 
from Costa Rica to southwestern Ecuador and in southeastern Venezuela [A. ocellata Gray, 1845; $A$. vittata Boulenger, 1913; A. bumanguesa Rueda-Almonacid \& Caicedo, 2004; A. rhombifera (Günther, 1859); A. escalerae Myers, Rivas \& Jadin, 2009].

Oftedal (1974) provided a comprehensive review of the genus, which is still authoritative and included 11 species. Since Oftedal's work five additional species have been described in the genus: two from Colombia (A. altaserrania and A. bumanguesa), one from the Venezuelan Andes (A. hobarti), one from the peninsula of Paria in Venezuela (A. pariaensis), and one from the La Escalera region, Bolívar State in southeastern Venezuela (A. escalerae), which to date constitutes the easternmost locality for the genus. Anadia pamplonensis was removed from the synonymy of A. bitaeniata by Harris \& Ayala (1987). The monophyly of the genus is still in question (Myers et al. 2009) and phylogenetic relationships are mostly unknown.

In 1978 Roy McDiarmid (Smithsonian Institution) accompanied by the Venezuelan explorer Charles Brewer-Carías collected an Anadia species on the summit of Murei-tepui in the Chimanta Massif (Gorzula 1992; McDiarmid \& Donnelly 2005). Although the species was supposed to be described by McDiarmid and Harris (as stated by Gorzula 1992), Gorzula (1992) reported it from the Chimantá Massif as Anadia breweri (a nomen nudum according to Gorzula \& Señaris 1999; Myers \& Donnelly 2008; and Myers et al. 2009) based on McDiarmid's specimen and additional material collected by the 'Grupo Científico Chimantá'. The species was subsequently reported as 'Anadia species a' by Gorzula \& Señaris (1999), who mentioned it from three tepuis in the Chimantá Massif: Abakapá-tepui, Amurítepui, and Murei-tepui, and as 'Anadia sp. A' by McDiarmid \& Donnelly (2005), who also reported it from the three same mountains. The species is illustrated as Anadia breweri in a recent book by BrewerCarías \& Audy (2010: unnumbered figure on page 210). Surprisingly, no description ever appeared and the status of the new species (including its generic allocation) remains uncertain.

A recent expedition to Abakapá-tepui in the Chimantá Massif led in the framework of a study on the evolution of the Pantepui herpetofauna resulted in the rediscovery of the species, which is described below on the basis of four specimens.

\section{Material and methods}

Specimens were collected by hand and euthanized by intra-peritoneal injection of 2\% Xylocaine. Whole individuals were fixed in 10\% formalin and later transferred to $70 \%$ ethanol for permanent storage. Specimens have been deposited in the collections of the Royal Belgian Institute of Natural Sciences (RBINS), Brussels, Belgium. Coordinates and elevations of localities were acquired using a Garmin 60CSx Global Positioning System unit and referenced to map datum WGS84.

Comparisons of external character states are based both on original descriptions and examination of museum specimens (see Appendix for material examined). Terminology for morphological characters and scale counts mostly follow Oftedal (1974) and Myers et al. (2009). All morphometric data were taken from the preserved specimens to the nearest $0.01 \mathrm{~mm}$ and rounded to the nearest $0.1 \mathrm{~mm}$, under a Leica stereo dissecting microscope using an electronic digital calliper. For ease of comparison, the description mainly follows the pattern of Myers et al. (2009). The following measurements and scale counts were taken and abbreviated as follows: (1) snout-vent length, from tip of snout to posterior margin of vent (SVL); (2) tail length, from posterior margin of vent to tip of tail (TL); (3) head length, from tip of snout to anterior margin of ear opening (HL); (4) greatest width of head (HW); (5) greatest depth of head (HD); (6) snout-axilla length (SAL); (7) neck length, from posterior edge of ear opening to forearm held at right angle to body (NL); (8) axilla-groin distance (= trunk length), from base of forelimb to base of hind limb (AXG); (9) forelimb length, from axilla to tip of claw of longest digit (FIL); (10) hind limb 
length, from groin to tip of claw of longest digit (HIL); (11) number of subdigital lamellae under Finger IV (SLF); (12) number of subdigital lamellae under Toe IV (SLT); (13) number of middorsal scales, from postoccipitals to the level of posterior edge of thigh held at right angle to body (MD); (14) number of ventrals in longitudinal rows, counted at midbody and including small ventrolateral rectangular plates (VL); (15) number of ventrals in transverse rows, counted between collar and vent [thus including preanals, which as pointed out by Oftedal (1974) are frequently difficult to distinguish from ventrals in the genus] (VT); (16) number of scales around midbody, counted at mid-distance between collar and vent (SAM); (17) number of supralabials (SL); (18) number of infralabials (IL); and (19) number of femoral pores under each thigh (FP).

Males' genitalia were everted in the field by injection of $10 \%$ formalin at the base of the tail just prior preservation. The left hemipenis of the holotype and both hemipenes of the adult male paratype (IRSNB 2674) were dissected in the laboratory, soaked over night in a solution of $2 \%$ potassium hydroxide, washed with distilled water, and filled with petroleum jelly, mostly following the methods described by Manzani \& Abe (1988) and modified by Pesantes (1994) and Zaher (1999). To highlight the calcareous spinules the organs were subsequently stained 24 hours in $1 \%$ potassium hydroxide saturated with Alizarin Red [method adapted from Uzzell (1973)], and stored in 70\% ethanol. Terminology of hemipenis description mostly follows Dowling \& Savage (1960), Savage (1997), Zaher (1999), and Myers et al. (2009).

Colour pattern in life was taken from field notes and colour digital photographs. Sex was determined by the presence/absence of hemipenes (base of tail dissected when hemipenes were not everted in the field). Taxonomy follows Oftedal (1974), Pellegrino et al. (2001) and Rodrigues et al. (2005). Institutional acronyms follow Frost (2011).

\section{Results}

Anadia mcdiarmidi sp. nov.

Figs 1-7, Table 1

Anadia breweri (nomen nudum) - Gorzula 1992: 276, figs 168-171

Anadia species a - Gorzula \& Señaris 1999: 114-115, fig. 88

Anadia sp. A - McDiarmid \& Donnelly 2005: 514

Anadia breweri (nomen nudum) - Brewer-Carías \& Audy 2010: 210, unnumbered figure

\section{Holotype}

IRSNB 2677 (field number PK 3565), 1 adult $\widehat{\jmath}$ collected by Philippe J.R. Kok, 03-05-2011 at 11h39, summit of Abakapá-tepui, Bolívar State, Venezuela, 05¹1'09"N 062¹7'36"W, 2201 m elevation.

\section{Paratopotypes}

( $\mathrm{n}=3) 1$ adult $\widehat{\partial}$ (IRSNB 2674, field number PK 3578) collected by Philippe J.R. Kok, 06-05-2011 at 9h40, summit of Abakapá-tepui, Bolívar State, Venezuela, 05¹0'50"N 062 17'49"W, 2242 m elevation); 1 juvenile $\widehat{\partial}$ (IRSNB 2675, field number PK 3577) collected by Philippe J.R. Kok, 06-05-2011 at 9h10, summit of Abakapá-tepui, Bolívar State, Venezuela, 05 $11^{\circ} 00^{\prime \prime} \mathrm{N} 062^{\circ} 17^{\prime} 34$ "W, 2200 m elevation; and 1 other juvenile ${ }^{\lambda}$ (IRSNB 2676, field number PK 3589) collected by Philippe J.R. Kok, 09-05-2011 at 9h00, summit of Abakapá-tepui, Bolívar State, Venezuela, 05¹1'07"N 062¹7'19"W, 2204 m elevation. 

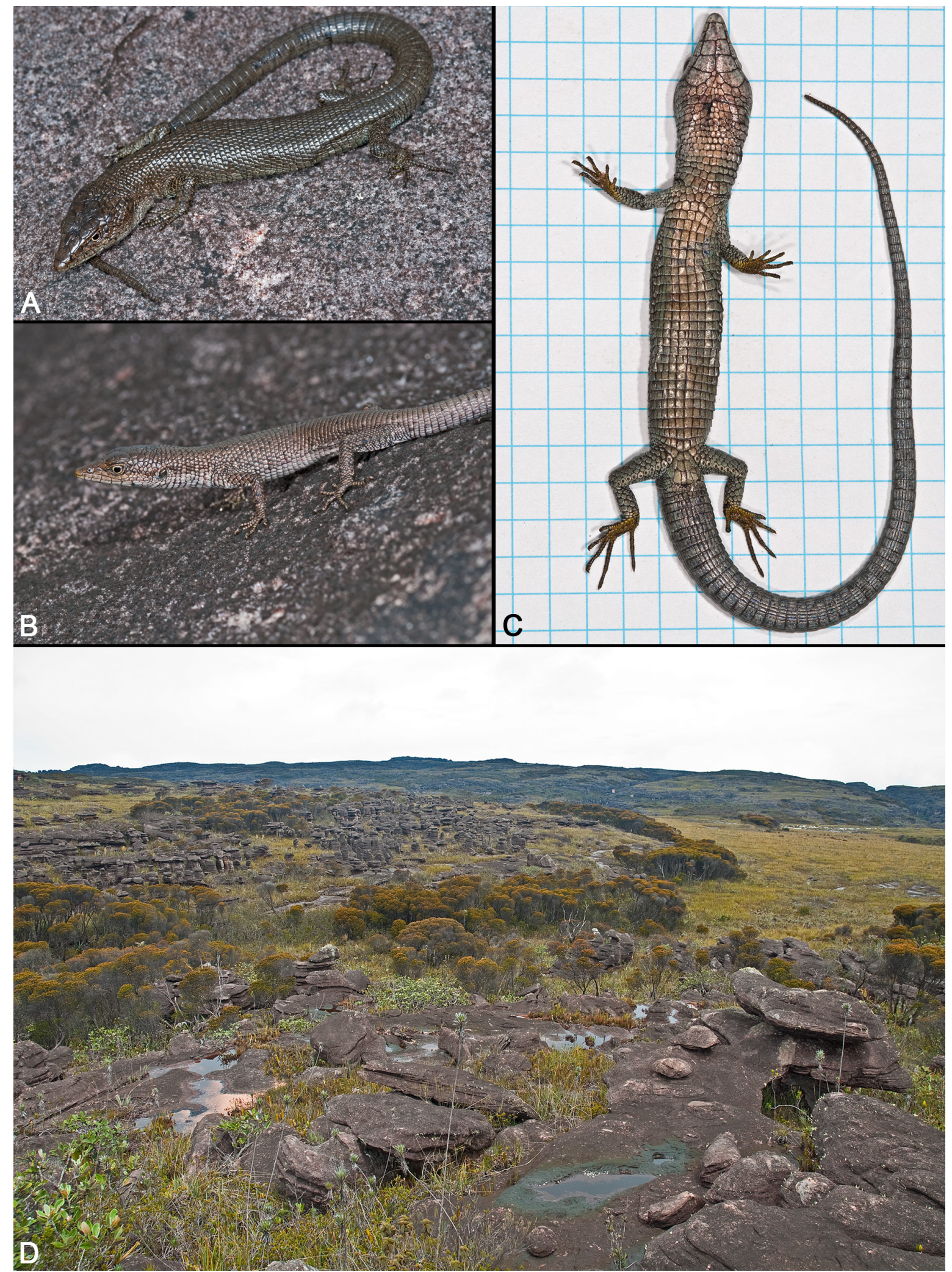

Fig. 1. Anadia mcdiarmidi sp. nov. A. IRSNB 2677, $ð$ holotype in life. B. IRSNB 2675, juvenile male paratype in life. C. Ventral view of the anaesthetized holotype (grid squares $=5 \mathrm{~mm}$ ). D. Summit of Abakapá-tepui, looking NW, showing the macrohabitat of the new species (03-05-2011). Photographs by Philippe J.R. Kok. 


\section{Etymology}

The specific epithet is a noun in the genitive case, honouring Roy McDiarmid, North American herpetologist (Smithsonian Institution), for his contribution to the knowledge of the Pantepui herpetofauna.

\section{Generic allocation}

The new species is placed in the genus Anadia because it fits the 11 diagnostic traits for the genus proposed by Oftedal (1974): dorsal scales smooth, essentially homogeneous; no distinct rows of much smaller scales between lateral scales; ventral scales smooth, quadrangular; head scales smooth, without striation; single frontonasal separating nasals; paired prefrontals; several large pigmented palpebrals; gular scales smooth, essentially homogeneous, with no distinctly enlarged longitudinal rows; 7-10 large preanal scales [maximum 9 in Oftedal (1974)]; femoral pores conspicuous in adult males; and limbs well developed, pentadactyl with all toes clawed.

\section{Definition and diagnosis}

A fairly robust species currently not assigned to any species group. The new species is characterized by the following combination of characters: (1) size small, body robust (maximum known SVL $62.2 \mathrm{~mm}$ ); (2) tail longer than SVL; (3) dorsal scales small, quadrangular; (4) middorsal scales 53-57; (5) suboculars large, unequal in size, with sometimes one scale slightly protruding downward between $4^{\text {th }}$ and $5^{\text {th }}$ supralabial, suboculars separated from palpebrals by 2-3 rows of mostly inconspicuous tiny scales, a few of them distinctly enlarged with angular downward protrusion between suboculars; (6) nasal entire, without sub-nostril groove; (7) 3-4 large pigmented palpebrals; (8) body uniform beige
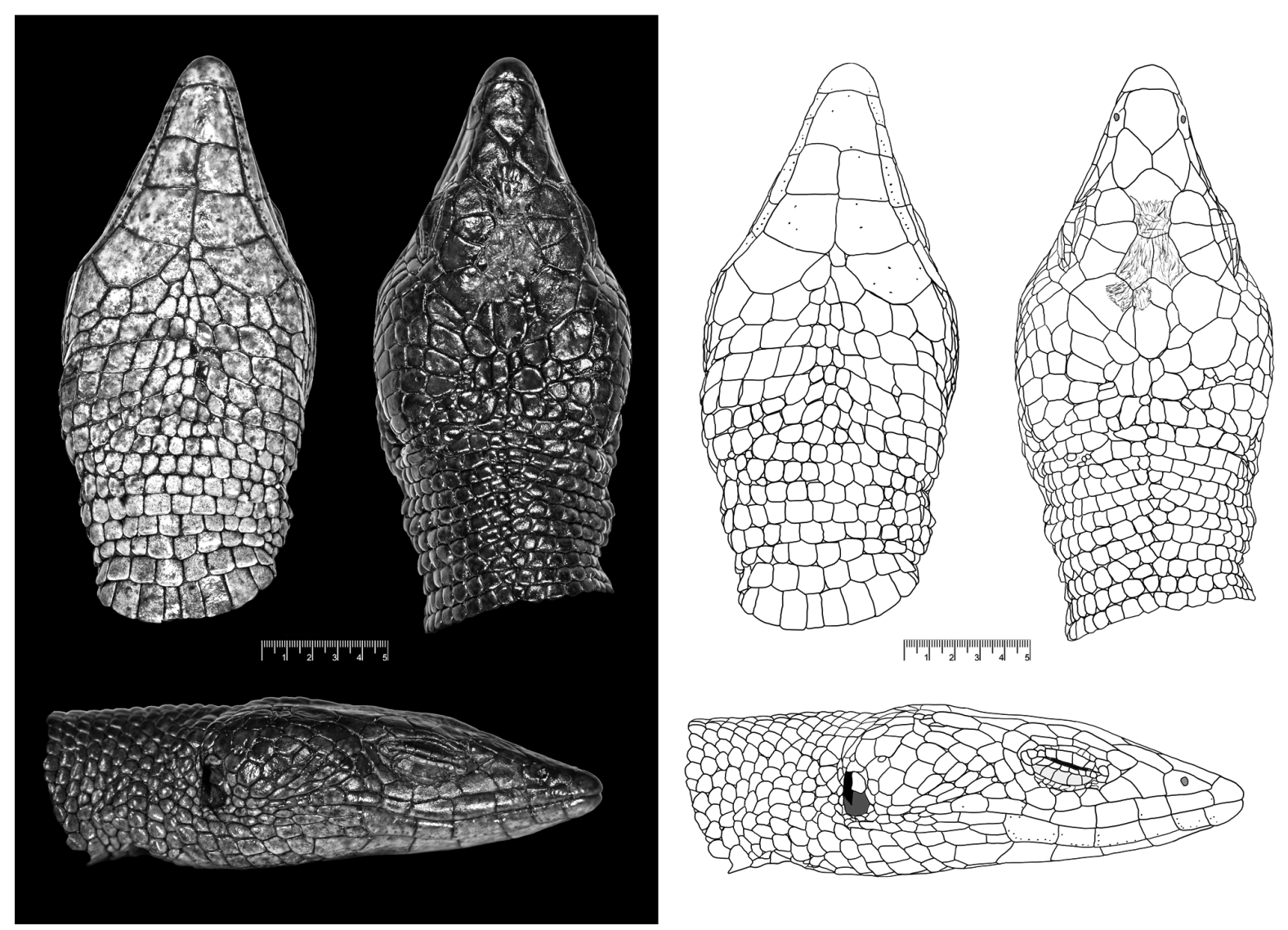

Fig. 2. Anadia mcdiarmidi sp. nov. Ventral, dorsal, and lateral views of the head of the holotype (IRSNB 2677). Scale lines $=5 \mathrm{~mm}$. Photographs by Philippe J.R. Kok. 
or greyish to bluish brown in life, devoid of any conspicuous pattern in males; (9) absence of any dark line on side of head in adult males; (10) venter immaculate golden grey in life; (11) femoral pores 9-10 on each side in males, unknown in females; (12) preanal pores absent; (13) hemipenis globose, weakly bilobed, bordered by numerous flounces ( $>20$, including about eight medioproximal asulcate flounces)

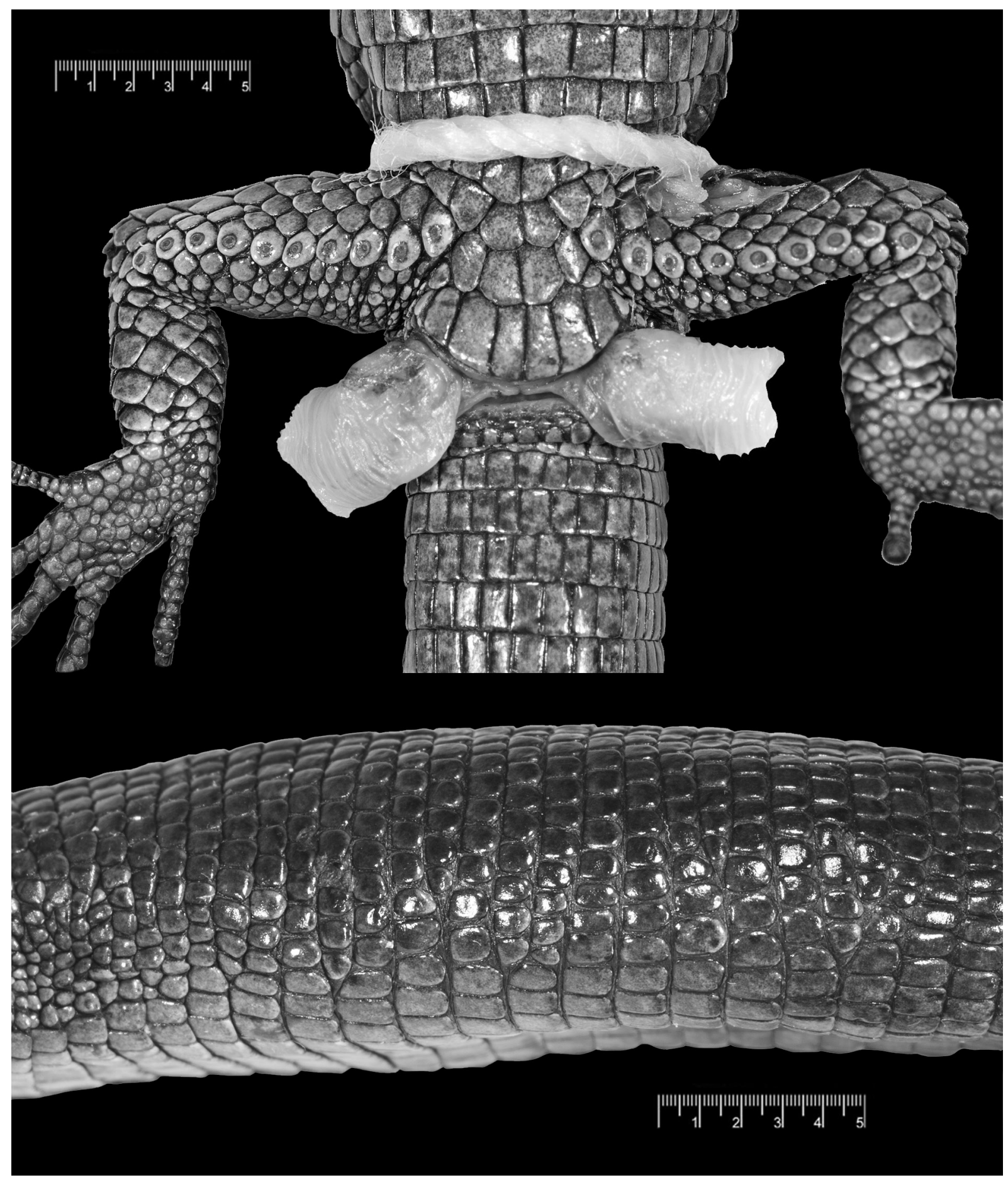

Fig. 3. Anadia mcdiarmidi sp. nov. Subpelvic region of the preserved $\delta$ holotype (IRSNB 2677), showing preanal scales and femoral pores, and trunk of the preserved holotype in lateral view (head to left), showing scalation at midbody. Scale lines $=5 \mathrm{~mm}$. Photographs by Philippe J.R. Kok. 


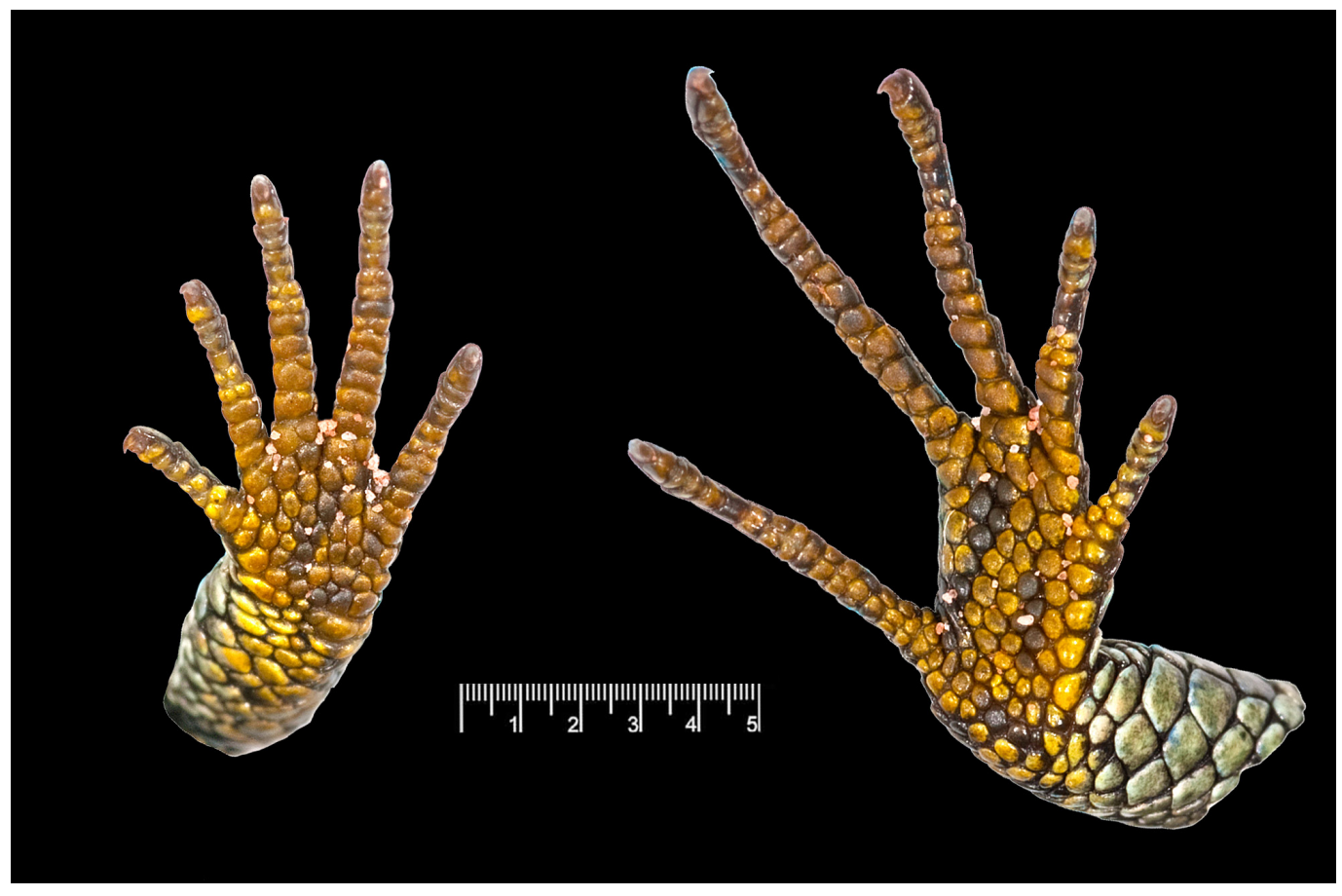

Fig. 4. Anadia mcdiarmidi sp. nov. Left hand and right foot of the holotype (IRSNB 2677) in life. Scale line $=5 \mathrm{~mm}$. Photographs by Philippe J.R. Kok.

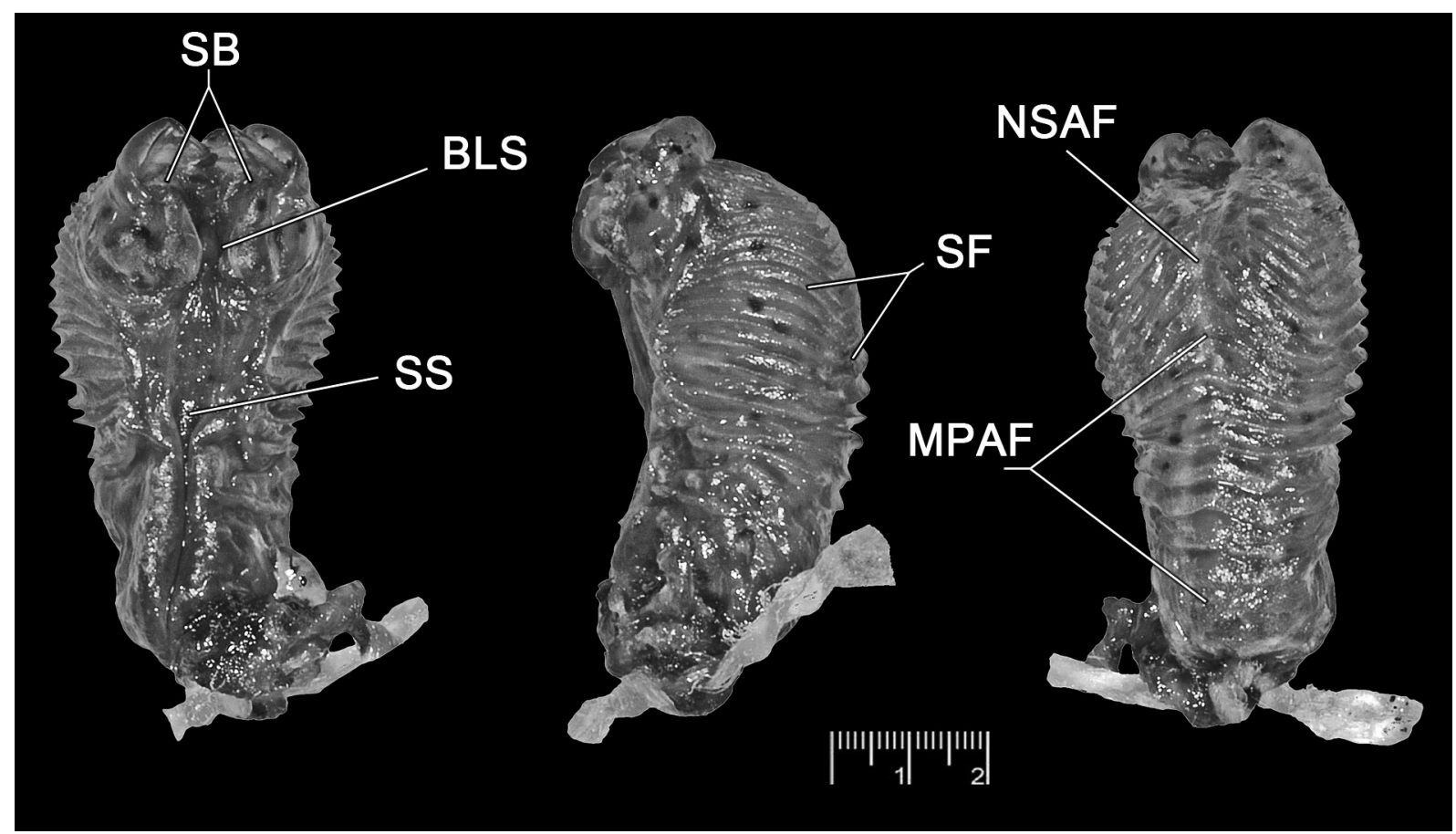

Fig. 5. Anadia mcdiarmidi sp. nov. The left fully everted — not maximally expanded—hemipenis of the holotype (IRSNB 2677). Left: sulcate side. Centre: lateral view, turned with sulcate side facing left. Right: asulcate side. BLS = fleshy bumplike structure; MPAF = medioproximal asulcate flounces; NSAF $=$ median nude space of the asulcate face; $\mathrm{SB}=$ sulcus branches; $\mathrm{SF}=$ spinulate flounces; $\mathrm{SS}=$ sulcus spermaticus. Scale line $=2 \mathrm{~mm}$. Although staining of the spinules by Alizarin Red is well visible under the microscope, the structures are not clearly observable in the figure. Photographs by Philippe J.R. Kok. 
bearing comblike rows of minute weakly mineralized spinules, sulcus spermaticus divided in the crotch by a small fleshy bumplike structure, sulcus branches barely detectable.

The new taxon is immediately distinguished from Anadia ocellata, A. vittata, A. rhombifera, and A. petersi [all members of the ocellata group of Oftedal (1974)] and A. bogotensis [single member of the bogotensis group of Oftedal (1974)] in having quadrangular dorsal scales (subhexagonal in species of the ocellata group, imbricate in A. bogotensis), and in lacking a subnostril groove or divided nasal (nasal divided or subnostril groove present in species of the ocellata group and in A. bogotensis); from A. altaserrania [a member of the bitaeniata group of Oftedal (1974) according to Harris \& Ayala (1987)] in having prefrontals (lacking in A. altaserrania), in having more femoral pores in males (9-10 in A. mcdiarmidi vs. 3-4 in A. altaserrania), and in having a higher number of middorsal scales (53-57 in A. mcdiarmidi vs. 45-47 in A. altaserrania); from A. bitaeniata, A. brevifrontalis, A. hobarti, A. pamplonensis, and A. pulchella [all members of the bitaeniata group of Oftedal (1974) according to La Marca \& García-Pérez (1990)] in having a higher number of middorsal scales (53-57 in A. mcdiarmidi vs. maximum 50 in species of the bitaeniata group); from A. blakei and A. marmorata [members of the marmorata group of Oftedal (1974)] in having a higher number of middorsal scales (more than 50 in A. mcdiarmidi vs. less than 35 in A. blakei and A. marmorata); from A. bumanguesa [a member of the bitaeniata group of Oftedal (1974) according to Rueda-Almonacid \& Caicedo (2004), but a possible synonym of $A$. steyeri and thus a member of the steyeri group of Oftedal (1974) according to Rivas et al. (in press)] in having a lower number of scales around midbody (35-36 in A. mcdiarmidi vs. 41 in A. steyeri), and in having pigmented palpebrals (unpigmented in A. bumanguesa); from A. pariaensis (not assigned to any species group in the original description) in having a much lower number of middorsal scales (5457 in A. mcdiarmidi vs. 70-72 in A. pariaensis); from A. steyeri [single member of the steyeri group of Oftedal (1974)] in having a lower number of scales around midbody (35-36 in A. mcdiarmidi vs. 40-45 in A. steyeri); and from A. escalerae (not assigned to any species group in the original description), the geographically closest relative, in having a robust body (slender in A. escalerae), in having smooth dorsal scales (weakly keeled in A. escalerae), in lacking dorsolateral stripes (present in A. escalerae), in having a lower number of middorsal scales (54-57 in A. mcdiarmidi vs. 63 in A. escalerae), and in having a lower number of scales around midbody (35-36 in A. mcdiarmidi vs. 40 in A. escalerae).

\section{Description of the Holotype}

An adult male in good condition (Figs 1A, C, 2, 3, 4, 6), with $62.2 \mathrm{~mm}$ SVL and $110.0 \mathrm{~mm}$ TL (see also Table 1). A rather robust Anadia species with moderately long limbs (digits overlap when limbs are adpressed along body). Snout attenuate, flat in profile. HL 25\% of SVL, 1.5 times longer than wide, 1.6 times wider than high; head conspicuously wider than neck. Neck long, $68 \%$ of HL, $35 \%$ of AXG. SAL $93 \%$ of AXG, $46 \%$ of SVL. Body wider than deep. Tail dorsoventrally flattened, about 1.8 times longer than SVL. Limbs pentadactyl with all digits clawed. Forelimb 27\% of SVL, 52\% of AXG; hind limb $36 \%$ of SVL, $73 \%$ of AXG.

Scutellation on the dorsal surface of head is typical for the genus [see fig. 1 in Oftedal (1974)], except the condition of the parietals and interparietal (see below and Figs 2, 7). The frontal is damaged, the frontoparietals are slightly damaged. Head scales are smooth with a few minute scattered pits, those pits are especially concentrated on the upper and posterior margins of supralabials, on the lower and posterior margins of infralabials, and on the posterior margin of rostral.

Rostral much wider than deep, laterally in contact with nasals and first supralabial, dorsally in contact with large frontonasal. Frontonasal with nearly straight anterior margin, posteriorly pointed. Paired prefrontals in contact, medial suture short. Frontal damaged, but obviously wider anteriorly and with blunt anterior point. Paired frontoparietals slightly damaged, with long medial suture, in contact with interparietal, parietals, and two posterior supraoculars. Three large supraoculars subequal in size. 
Interparietal divided into about two scales unequal in size. Parietals not extending as far as interparietal posteriorly, divided into two scales on the left side, into four scales on the right side. A series of six small to large occipitals (postparietals) circling the common posterior margin of parietals and interparietal.
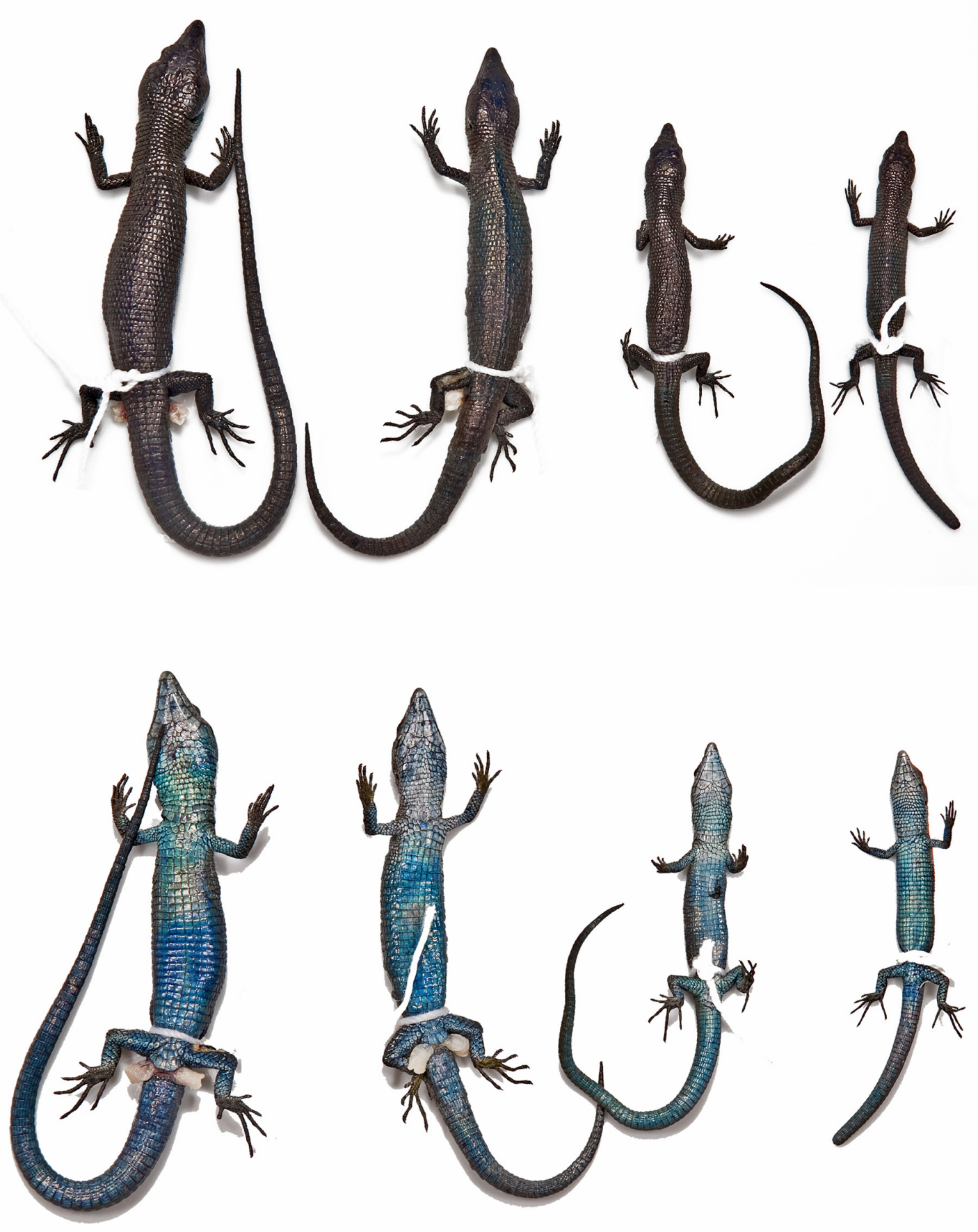

Fig. 6. Anadia mcdiarmidi sp. nov. Intrapopulation variation in dorsal (above) and ventral (below) colour pattern in preserved specimens. From left to right: IRSNB 2677, IRSNB 2674, IRSNB 2676, IRSNB 2675. Photographs by Philippe J.R. Kok. 
Nasal scale entire, with a small indentation situated anterodorsally to nostril on the left side. Nasal scale in contact with rostral, posteriorly in contact with prefrontal, and in broad contact with loreal. Loreal large, pentagonal, in broad contact with first superciliary (= presuperciliary) and frenocular, in point contact with preocular. One small preocular, three postoculars. First superciliary large, followed by four shorter superciliaries. No small azygous scale between superciliaries and supraoculars. Frenocular followed posteriorly by three suboculars. Third subocular slightly extending to lip between supralabials 4-5 on the left side only. Suboculars separated from palpebrals by 2-3 poorly defined rows of mostly inconspicuous tiny scales, two of them distinctly enlarged with angular downward protrusion between suboculars. Seven supralabials.

Eight ciliaries along upper eyelid. Lower eyelid scales translucent, slightly pigmented, with four higherthan-wide palpebrals.

Temporal scales subimbricate, smooth, with flat surfaces, slightly larger above and smaller below. Ear opening broad, ovoid, slightly inclined posterodorsally, edged with small, slightly pebblelike scales; tympanum recessed, pigmented.
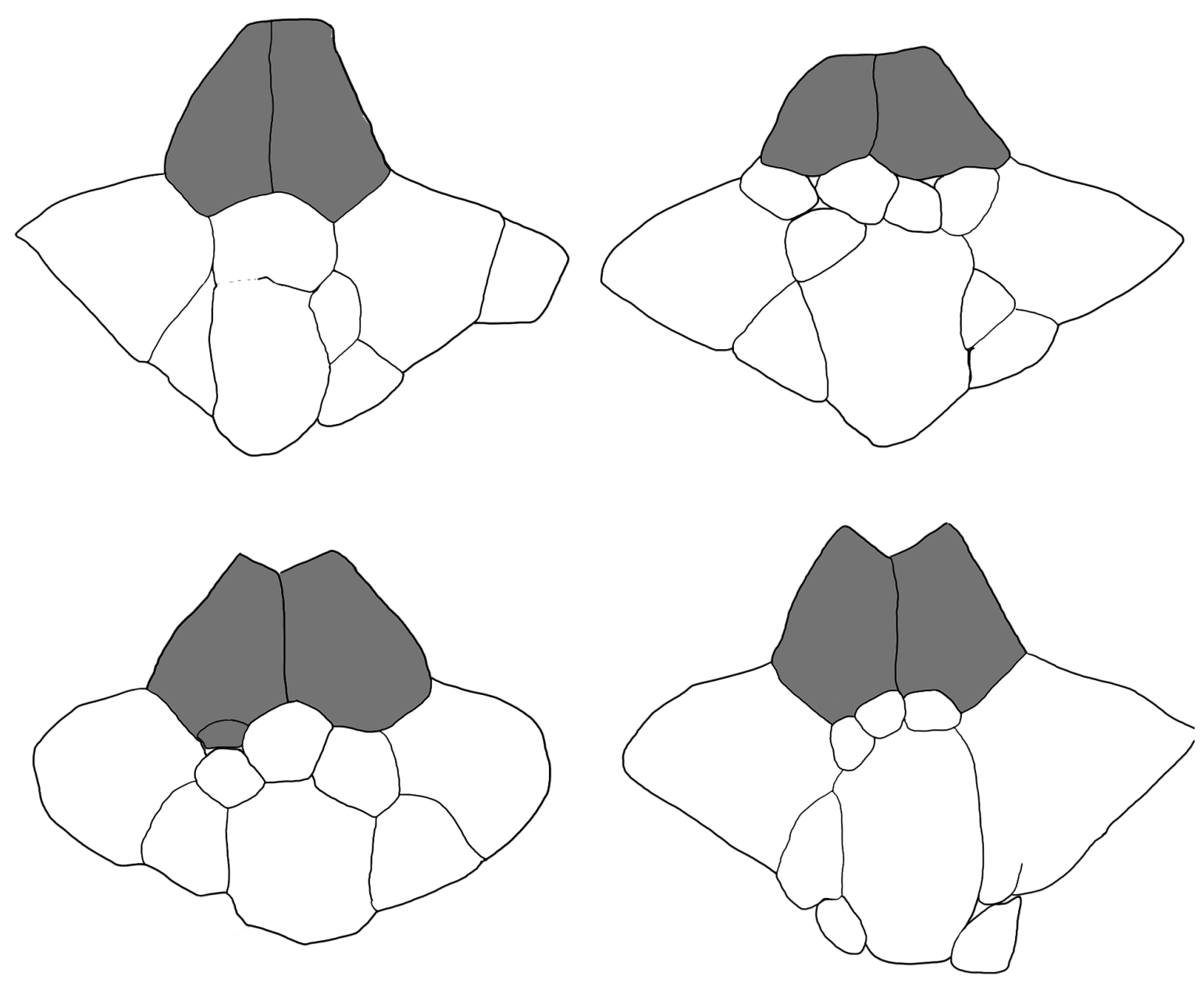

Fig. 7. Anadia mcdiarmidi sp. nov. Intrapopulation variation in the condition of the parietals and the interparietal (frontoparietals in grey). Top, from left to right: IRSNB 2677, IRSNB 2676; bottom, from left to right: IRSNB 2675, IRSNB 2674. Drawings not to scale. 
Underside of head with six infralabials on each side. A large mental followed by a large postmental in contact with first two infralabials. Two pairs of large genials in broad contact medially, in lateral contact with infralabials 3-4; two pair of postgenials, the first pair large, each scale in contact with last genial and infralabials 4-5, the second pair much smaller, each scale in contact with first postgenial and in point contact with fifth infralabial. Gulars arranged in transverse rows, becoming slightly larger posteriad, culminating in a well-defined collar row of eight subequal scales; no distinctly enlarged longitudinal rows. Side of neck between ear and collar pebbled with subequal irregularly shaped juxtaposed scales.

Middorsal scales 54. Dorsal scales on neck subimbricate, irregularly shaped, with rounded surfaces. Dorsal body scales smooth, juxtaposed, mainly quadrangular, a few irregularly shaped, but most are longer than wide, in transverse rows only. Lateral scales smooth, similar to dorsals, but smaller.

Ventral scales much wider than dorsals, smooth, juxtaposed, quadrangular, slightly longer than wide except for $c a$. four median longitudinal rows of square to wider than long scales on belly; in 14 longitudinal rows at midbody and 31 transverse rows between collar and vent.

Eight marginal preanal scales anterior to vent, the middle two narrower than the adjacent lateral ones, most outer ones very small. Femoral pores well developed, in swollen pore scales mostly in linear contact; 9 pores on left thigh, 10 on right. Pores do not extend onto preanal area (Fig. 3).

Caudal scales smooth, subimbricate, rectangular, in transverse rows around tail.

Scales on dorsal surfaces of arm large, smooth, imbricate; ventral surfaces of arm with similar, but smaller and less imbricate scales. Hind limbs with large, smooth subimbricate to imbricate scales on anterior face of thighs and on lower legs; scales similar but smaller on ventral side of thigh. Dorsal and posterior sides of thigh with much smaller, irregularly shaped juxtaposed scales.

Moderate-size, imbricate scales atop hands and feet. Supradigital scales single; upper and lower ungualsheath scales covering base of claws, leaving tips well exposed. Palms and soles with small slightly raised juxtaposed scales (Fig. 4). Two enlarged smooth thenar scales at base of pollex. Subdigital lamellae mostly single. Lamellae under first (I) through fifth (V) finger (right/left side): I: 7/6, II: 9/9, III: 11/11, IV: 13/14, V: 10/9. Lamellae under first (I) through fifth (V) toe (right/left side): I: $6 / 6$, II: 10/10, III: 14/12, IV: 17/15, V: 15/6 (large part of Toe V missing on left side).

Tongue lanceolate; proximal two-third unpigmented, distal one-third heavily pigmented, including fork. Upper surface behind fork covered with imbricate scalelike papillae that extend onto ventrolateral sides of tongue. Raised medioventral side of tongue with numerous $(>10)$ of thin, oblique, anteriorly converging and pointed (chevronlike) infralingual plicae; anterior pair of plicae swollen, bluntly pointed and larger than those following. Very shallow medioventral groove.

Anterior maxillary and dentary teeth conical, unicuspid, with no or very feeble recurvature, becoming larger posteriorly.

The left hemipenis (Fig. 5) extends about four subcaudal rows when adpressed to the tail, and is about $7.0 \mathrm{~mm}$ in length and $4.0 \mathrm{~mm}$ across its widest point when fully everted (organ not maximally expanded because one of the lobes was slightly damaged during the eversion process). Hemipenial body globose, tapered near the base, weakly and symmetrically bilobed. Sulcus spermaticus broader near crotch, relatively shallow, curving about halfway around the base of the organ, then running medially towards the lobes. Sulcus flanked by a narrow nude area on each side, and divided in the crotch by a small fleshy bumplike structure, from where two narrow, ill-defined and barely detectable sulcus branches seem to extend laterally into the folded thickened 'ear-like' tissues of each lobe towards the apices of the 


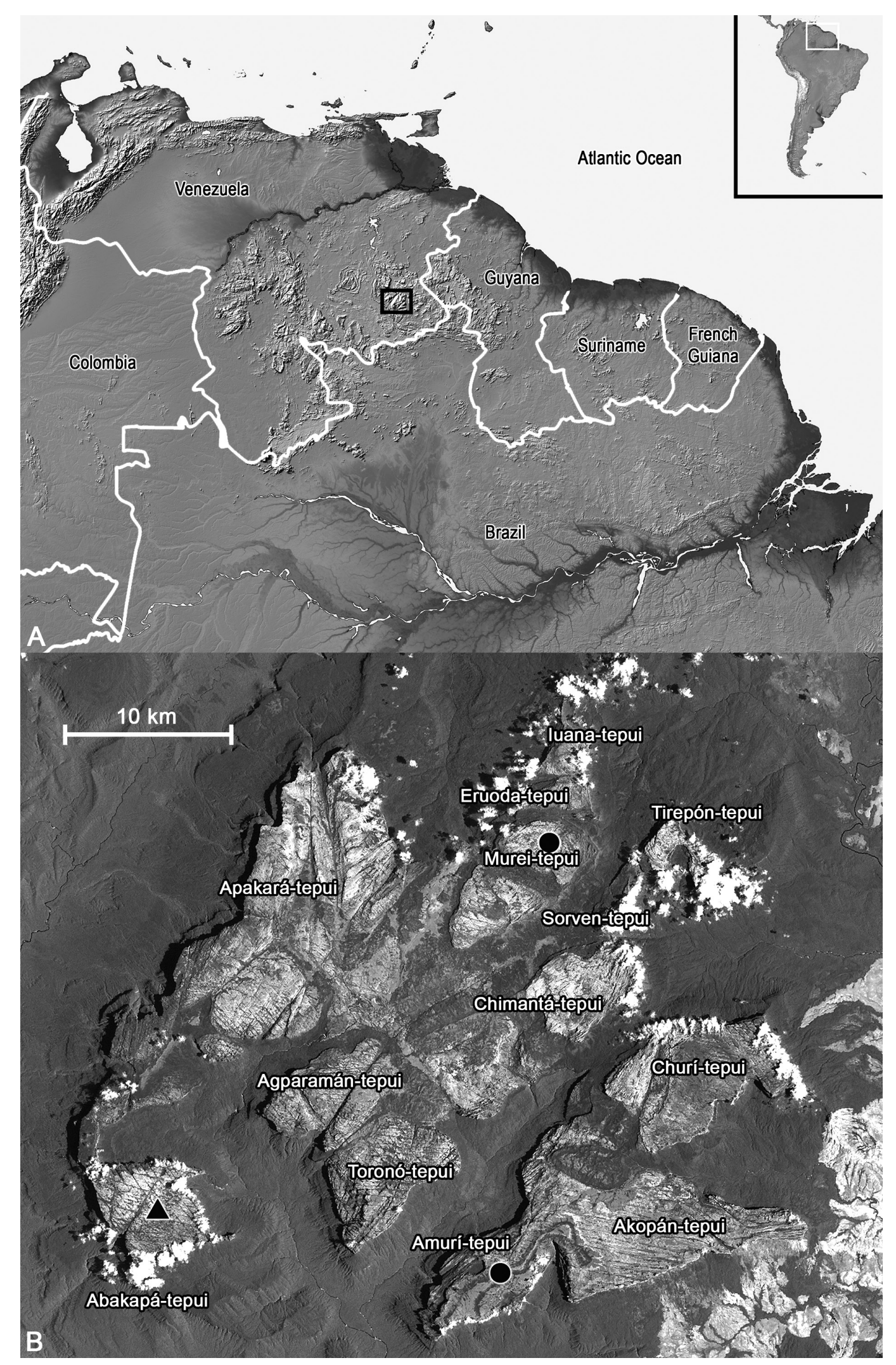

Fig. 8. Map of the Guiana Shield region (A), with enlarged black rectangle corresponding to the Chimantá Massif(B). Black triangle indicates type locality, black dots indicate other know localities for the species. 
lobes. Lobes are complexly folded, not flattened terminally, and sulcus branches seem to end in small depressions (from which residual seminal fluid was removed before hemipenis preparation).

Very base of hemipenis nude, pigmented in life. Lateral and asulcate faces of the organ with a series of roughly equidistant oblique plicae or flounces with weakly calcified spinules. Twenty-three rows of flounces extending along the organ. Basal flounces shorter, almost in straight transverse lines, the three first rows almost continuous across the hemipenial base, except for narrow nude areas on each lateral face and for nude areas edging each side of the sulcus spermaticus; five subsequent rows continuous across hemipenial body (except for nude areas edging each side of the sulcus spermaticus), with the seventh and eight rows distinctly pointing medially towards the apex on the asulcate face (those eight flounces proximal to the median nude space of the asulcate face correspond to the 'medioproximal asulcate flounces' sensu Myers et al. 2009); fifteen remaining rows chevron-shaped, also circling the organ, but separated by a broad median nude space on the asulcate face and by the nude areas edging each side of the sulcus spermaticus. The plicae bear comblike rows of minute weakly mineralized spinules that project slightly from the edges of the plicae and usually increase in size towards the lateral faces and the basal part of the organ (staining of the spinules by Alizarin Red is well visible under the microscope although not observable in Fig. 5).

\section{Colour of the Holotype in life}

Dorsum greyish to bluish brown depending on light intensity, devoid of any conspicuous pattern, but with a few scattered black scales on flanks. Arms and legs, including digits, greyish brown with a few scattered black scales; rear of thighs with a few ill-defined dark markings. Ventral surfaces of head and body golden grey, ventral surfaces of legs and tail bluish grey, palms and soles lemon yellow speckled with brown and yellowish orange scales. Tympanum dark brown, iris pale yellow (Figs 1A, C, 4).

\section{Colour of the Holotype in preservative}

After approximately two months in preservative, the dorsal surfaces became dark brown (looking slightly peppered when specimen is in liquid), the ventral surfaces are metallic blue, except the anterior surface of head, which is light grey (Fig. 6). Palms and soles are grey. Tympanum is dark brown. It is worthwhile to note that the ventral skin, and some parts that are light grey (like the anterior underside of head), turn blue or bluer when pressure is applied to the skin.

\section{Variation in paratypes}

The paratypes consist in 1 adult $\hat{\sigma}$ (SVL $60.4 \mathrm{~mm}$ ), and 2 juvenile $\widehat{\delta}$ (SVL from 38.2 to $42.6 \mathrm{~mm}$ ). Table 1 provides measurements of the type series, and Fig. 1B shows one of the juvenile paratypes in life (IRSNB 2675).

One of the main differences among specimens of the type series is the occurrence of a presupraocular scale in the three paratypes (absent in the holotype); that presupraocular scale is divided on both sides in IRSNB 2675. IRSNB 2676 has four suboculars on both sides (vs. three in the holotype and other paratypes). Supralabial counts are consistent, but infralabial counts vary from $5(n=1)$ to $7(n=1$, one side only). Pits on head scales are inconspicuous in the two juveniles ( $v s$. well visible in the adult males). Suboculars are always separated from palpebrals by 2-3 poorly defined rows of inconspicuous tiny scales. In IRSNB 2674 three of these scales (vs. two in the holotype) are distinctly enlarged (larger than in holotype) with angular downward protrusion between suboculars. In both juvenile paratypes, only one of these scales is only slightly enlarged and slightly protrudes between suboculars. The condition of the parietals and interparietal is highly variable among specimens and none of the specimens examined has complete interparietal and parietals, which are always divided in several smaller scales (see Fig. 7 for comparison). Number of middorsal scales varies from 53 to 57 . Ventrals are in 11 to 14 longitudinal 
rows and in 29 to 30 transverse rows. The number of femoral pores varies from 8 to 10 . Preanals vary from 7 to 10 .

The fully everted, maximally expanded, right hemipenis of the adult $\widehat{ } \widehat{ }$ paratype (IRSNB 2674) is identical to the holotype's organ, except that maximal expansion makes the sulcus spermaticus bifurcation and the sulcus branches even more difficult to appreciate. Maximal expansion does not highlight hemipenial features that would have been overlooked in the not maximally expanded hemipenis of the holotype. The hemipenis is $6.6 \mathrm{~mm}$ in length and $4.0 \mathrm{~mm}$ across its widest point when everted; there are twentyfour rows of flounces extending along the organ, $c a$. eight of which are medioproximal asulcate flounces.

Colour in life ranges from beige to dark greyish, sometimes bluish, brown dorsally, depending on light intensity. Rear of thighs usually has a few ill-defined dark markings. Some blue markings may be visible around ear, or at the base of the tail, or on ventral parts. Ventral parts range from golden grey to pale yellow. One of the juvenile paratypes (IRSNB 2675, see Fig. 1B) has two poorly defined dark

Table 1. Sex, measurements (in $\mathrm{mm}$ ) and scale counts of the type series of Anadia mcdiarmidi sp. nov. ${ }^{1}=$ tail incomplete or obviously regenerated, ${ }^{2}=$ data corresponding to right/left side, other abbreviations are defined in the text.

\begin{tabular}{|c|c|c|c|c|}
\hline Specimen & IRSNB 2677 & IRSNB 2674 & IRSNB 2675 & IRSNB 2676 \\
\hline Sex & $\hat{0}$ & $\pi$ & Juvenile $\delta^{\lambda}$ & Juvenile $\sigma^{\lambda}$ \\
\hline SVL & 62.2 & 60.4 & 38.2 & 42.6 \\
\hline $\mathrm{TL}$ & 110.0 & $57.0^{1}$ & $29.7^{1}$ & 74.0 \\
\hline HL & 15.8 & 13.6 & 9.0 & 10.2 \\
\hline HW & 10.8 & 8.7 & 5.8 & 6.6 \\
\hline HD & 6.7 & 5.7 & 3.9 & 4.4 \\
\hline SAL & 28.4 & 23.8 & 14.6 & 18.9 \\
\hline NL & 10.8 & 6.7 & 5.2 & 6.0 \\
\hline AXG & 30.7 & 29.9 & 18.4 & 19.8 \\
\hline FIL & 16.6 & 16.6 & 10.2 & 11.6 \\
\hline HIL & 22.4 & 18.5 & 14.3 & 15.6 \\
\hline SLF & $13 / 14^{2}$ & $14 / 13^{2}$ & $12 / 13^{2}$ & $13 / 14^{2}$ \\
\hline SLT & $17 / 17^{2}$ & $17 / 17^{2}$ & $17 / 15^{2}$ & $17 / 17^{2}$ \\
\hline $\mathrm{MD}$ & 54 & 53 & 53 & 57 \\
\hline VL & 14 & 12 & 14 & 11 \\
\hline VT & 31 & 29 & 31 & 30 \\
\hline SAM & 36 & 35 & 35 & 35 \\
\hline $\mathrm{SL}$ & $7 / 7^{2}$ & $7 / 7^{2}$ & $7 / 7^{2}$ & $7 / 7^{2}$ \\
\hline IL & $6 / 6^{2}$ & $6 / 6^{2}$ & $7 / 6^{2}$ & $5 / 5^{2}$ \\
\hline FP & $10 / 9^{2}$ & $9 / 9^{2}$ & $9 / 8^{2}$ & $10 / 10^{2}$ \\
\hline
\end{tabular}


brown stripes between eye and ear. In preservative all specimens became dark brown dorsally, looking slightly peppered when in liquid. Ventral parts are always metallic blue (Fig. 6). Tympanum in preserved specimens varies from dark brown to blue or golden blue.

\section{Distribution and ecology}

The new species is known only from the Chimantá Massif in Venezuela (Fig. 8) where it has been reported from Abakapá-tepui (type locality), Amurí-tepui, and Murei-tepui (sometimes named Eruodatepui, see Discussion) between ca. 2100-2600 m elevation (McDiarmid \& Donnelly 2005). The species is probably widespread in the Chimantá Massif.

Anadia mcdiarmidi is diurnal and inhabits open, mostly flat sandstone areas on tepui summits (Fig. 1D). The holotype and two paratypes were collected during the day under rocks; IRSNB 2674 was found during the day, crawling in a small crack between rocks. Two white fertile eggs (both measuring $12.3 \mathrm{~mm}$ ) and several older eggshells attributable to the new species were found under a large rock, suggesting that a same suitable nesting site may be reused [as already postulated by Gorzula (1992)], and that females lay two eggs at a time. The only other lizard found syntopic with Anadia mcdiarmidi was Neusticurus cf. rudis, which was also mainly found under rocks.

\section{Discussion}

As stated above, the new species has been mentioned previously in four publications: Gorzula (1992), Gorzula \& Señaris (1999), McDiarmid \& Donnelly (2005), and Brewer-Carías \& Audy (2010), but none of these publications provides any comprehensive morphometric data, except a SVL of $86 \mathrm{~mm}$ and a TL of $77 \mathrm{~mm}$ (suggesting a broken tail) in a large adult male (catalogued as MHNLS 10772, probably the largest known specimen), and a SVL of $65 \mathrm{~mm}$ in a gravid female catalogued as MHNLS 10765 (Gorzula \& Señaris 1999). The few published photographs [figs 168-171 in Gorzula (1992), fig. 88 in Gorzula \& Señaris (1999), and an unnumbered figure on page 210 in Brewer-Carías \& Audy (2010)] and data (Gorzula 1992; Gorzula \& Señaris 1999) conform to the new species description and add the following information: (1) large males obviously have a wider head than females, a character shared by several Anadia species (e.g. A. bogotensis, A. brevifrontalis, A. petersi, A. rhombifera), (2) females may have one or two faint darker stripes between orbit and ear (as also seen in one of our juvenile male paratypes), (3) the known maximal size in the species is apparently $86 \mathrm{~mm}$ SVL.

Although Eruoda-tepui and Murei-tepui (occasionally spelled Murey-tepui) are sometimes considered the same mountain (e.g. Gorzula \& Señaris 1999), we consider them as separate tepuis (see Fig. 8). McDiarmid \& Donnelly (2005) provide $05^{\circ} 22^{\prime} \mathrm{N}, 062^{\circ} 05^{\prime} \mathrm{W}$ as the coordinates for Murei-tepui, and clearly mention that it is the locality where Anadia sp. A (here described as Anadia mcdiarmidi) has been collected. Eruoda-tepui is located north to Murei-tepui, and no report of the new species has been recorded from that mountain yet.

Pellegrino et al. (2001) tentatively assigned the genus Anadia to the family Cercosaurinae (tribe Cercosaurini) on the basis of morphology and our preliminary molecular results (Kok, unpublished) corroborate this. Members of the genus Anadia have not been included in any modern phylogenetic study and relationships between species, as well as their relationships with apparently close genera like Euspondylus, remain unknown. The genus Euspondylus Tschudi, 1845 is ill defined (see Oftedal 1974; Myers et al. 2009) and is mainly distinguished from Anadia by the presence of distinct rows of much smaller scales between lateral scales (in Anadia lateral scales are subequal and mostly in unbroken transverse rows with dorsal scales). A single study was conducted to test the phylogenetic position of Euspondylus acutirostris (Peters, 1863) based on its cranial osteology and myology (Montero et al. 2002). Results from Montero et al. (2002) show E. acutirostris nested in a clade containing three species 
of Anadia, thus suggesting that both genera are synonyms. However, Myers et al. (2009: 11) highlighted that one of the E. acutirostris specimens used by Montero and colleagues could have been misidentified and could actually be an Anadia marmorata, which is currently impossible to determine because that specimen was dissected for the osteological portion of their study. Therefore, the phylogenetic position of Anadia, intrageneric relationships within Anadia, and relationships to Euspondylus remain an enigma.

Based on morphology only it is challenging to infer relationships of the new taxon with other Anadia species because many characters of the new species could be adaptations to high mountain habitat, and thus shared by other high mountain species that may not be closely related. At this stage the lack of adequate tissue sampling among Anadia species hampers any sound molecular analyses.

The origin of the Pantepui biodiversity still remains an evolutionary enigma (e.g. Rull 2009) and the discovery of a species of Anadia (primarily an Andean genus) apparently endemic to tepui summits is of considerable interest to the understanding of the processes underlying the origin and evolution of the Pantepui herpetofauna. This matter is beyond the scope of this paper and is subject of ongoing research that will be presented elsewhere.

\section{Acknowledgements}

The partial financial support from the King Léopold III Fund for Nature Exploration and Conservation to PJRK is gratefully acknowledged. PJRK thanks B. Wilson for field companionship and C. BrewerCarías for clarification about some tepui names. Finally, we warmly thank R. Jadin and P. Sales Nunes whose comments improved a previous version of this paper, and F. Bisbal, E. Camargo, D. Mora and D. Sánchez (EBRG) for the loan of specimens under their care and various help.

\section{References}

Boulenger G.A. 1903. Descriptions of new lizards in the collection of the British Museum. Annals and Magazine of Natural History (7) 12: 429-435.

Boulenger G.A. 1913. On a collection of Batrachians and Reptiles made by Dr. H.G.F. Spurrell, F.Z.S., in the Choco, Colombia. Proceedings of the Zoological Society of London 83 (4): 1019-1038. http://dx.doi.org/10.1111/j.1096-3642.1913.tb02003.x

Brewer-Carías C. \& Audy M. 2010. Entrañas del Mundo Perdido. Carlos Capriles de Altolitho C.A., Caracas.

Dowling H.G. \& Savage J. 1960. A guide to the snake hemipenis: a survey of basic structure and systematic characteristics. Zoologica 45: 17-28.

Dunn E.R. 1944. The lizard genus Anadia and Ptychoglossus in Colombia. Caldasia 3: 63-68.

Frost D.R. 2011. Amphibian Species of the World: an Online Reference. Version 5.5 (31 January, 2011). American Museum of Natural History, New York, USA.

Available at: http://research.amnh.org/herpetology/amphibia/index.php [Access in: July 2011].

Gorzula S. 1992. La herpetofauna del macizo del Chimantá. In: Huber O (ed.), El Macizo del Chimantá: 267-280, 304-310. Oscar Todtmann Editores, Caracas.

Gorzula S. \& Señaris J.C. 1999 "1998”. Contribution to the herpetofauna of the Venezuelan Guayana: I. A data base. Scientia Guaianae 8: 1-269. 
Gray J.E. 1845. Catalogue of the specimens of lizards in the collection of the British Museum. Trustees of die British Museum/Edward Newman, London.

Gray J.E. 1846. Description of a new family and genus of lizards from Colombia. Annals and Magazine of Natural History 18: 67.

Günther A. 1859. Second list of cold-blooded vertebrata collected by Mr. Fraser in the Andes of Western Ecuador. Proceedings of the Zoological Society of London: 402-422.

Harris D.M. \& Ayala S.C. 1987. A new Anadia (Sauria: Teiidae) from Colombia and restoration of Anadia pamplonensis Dunn to species status. Herpetologica 43 (2): 182-190.

La Marca E. \& García-Pérez J.E. 1990. A new species of high Andean Anadia (Sauria: Teiidae) from Páramo El Riecito, Estado Trujillo, Venezuela. Herpetologica 46 (3): 275-282.

Manzani P.R. \& Abe A.S. 1988. Sobre dois novos métodos de preparo de hemipenis de serpentes. Memórias do Instituto Butantan 50: 15-20.

McDiarmid R.W. \& Donnelly M.A. 2005. The herpetofauna of the Guayana Highlands: amphibians and reptiles of the Lost World. In: Donnelly M.A., Crother B.I., Guyer C., Wake M.H. \& White M.E. (eds.) Ecology and Evolution in the Tropics: A Herpetological Perspective: 461-560. University of Chicago Press, Chicago, Illinois.

Montero R., Moro S.A. \& Abdala V. 2002. Cranial anatomy of Euspondylus acutirostris (Squamata: Gymnophthalmidae) and its placement in a modern phylogenetic hypothesis. Russian Journal of Herpetology 9 (3): 215-228.

Myers C.W. \& Donnelly M.A. 2008. The summit herpetofauna of Auyantepui, Venezuela: report from the Robert G. Goelet American Museum-Terramar Expedition. Bulletin of the American Museum of Natural History 308: 1-147. http://dx.doi.org/10.1206/308.1

Myers C.W., Rivas Fuenmayor G. \& Jadin R.C. 2009. New species of lizards from Auyantepui and La Escalera in the Venezuelan Guayana, with notes on "microteiid" hemipenes (Squamata: Gymnophthalmidae). American Museum Novitates 3660: 1-31. http://dx.doi.org/10.1206/657.1

Nieden F. 1914. Beschreibung einer neuen Tejiden-Art nebst Bemerkungen über einige Kriechtiere des Naturhistorischen Museum in Lübeck. Sitzungsberichte der Gesellschaft naturforschender Freunde zu Berlin: 364-366.

Oftedal O.T. 1974. A revision of the genus Anadia (Sauria, Teiidae). Arquivos de Zoologia, São Paulo 25 (4): 203-265.

Pellegrino K.C.M., Rodrigues M.T., Yonenaga-Yassuda Y. \& Sites Jr. J.W. 2001. A molecular perspective on the evolution of microteiid lizards (Squamata, Gymnophthalmidae), and a new classification for the family. Biological Journal of the Linnean Society 74: 315-338. http://dx.doi.org/10.1006/bij1.2001.0580

Pesantes O. 1994. A method for preparing the hemipenis of preserved snakes. Journal of Herpetology 28: 93-95. http://dx.doi.org/10.2307/1564686

Peters W. 1863. Über Cercosaura und die mit dieser Gattung verwandten Eidechsen aus Südamerika. Abhandlungen der Königlichen Akademie der Wissenschaften zu Berlin 1862: 165-225.

Rivas G.A., Sales Nunes P.M., Dixon J.R., Schargel W.E., Caicedo J.R., Barros T.R., Camargo E.G. \& Barrio-Amorós C.L. In press. Taxonomy, hemipenial morphology and natural history of two poorly known species of Anadia (Gymnophthalmidae) from northern South America. Journal of Herpetology.

Rivas Fuenmayor G., La Marca E. \& Oliveros O. 1999. Una nueva especie de Anadia (Reptilia: Sauria: Gymnophthalmidae) del noreste de Venezuela. Acta Biológica Venezuelica 19 (4): 27-32. 
Rodrigues M.T., Freire E.M.X., Pellegrino K.C.M. \& Sites Jr. J.W. 2005. Phylogenetic relationships of a new genus and species of microteiid lizard from the Atlantic forest of north-eastern Brazil (Squamata, Gymnophthalmidae). Zoological Journal of the Linnean Society 144: 543-557.

http://dx.doi.org/10.1111/j.1096-3642.2005.00177.x

Rueda-Almonacid J.V. \& Caicedo J.R. 2004. Una nueva especie de Anadia (Reptilia: Sauria: Gymnophthalmidae) para el noroccidente de la cordillera oriental de Colombia. Revista de la Academia Colombiana de Ciencias Exactas, Físicas y Naturales 28 (107): 281-284.

Rull V. 2009. Pantepui. In: Gillespie R.G. \& Clague D.A. (eds.) Encyclopedia of Islands: 717-720. University of California Press, Berkeley.

Ruthven A.G. 1926. A new species of Anadia from the Santa Marta Mountains, Colombia. Occasional Papers of the Museum of Zoology, University of Michigan 177: 1-3.

Savage J.M. 1997. On terminology for the description of the hemipenis of squamate reptiles. Herpetological Journal 7: 23-25.

Schmidt K.P. 1932. Reptiles and amphibians of the Mandel Venezuelan Expedition. Field Museum of Natural History, Zoological Series 18 (7): 159-163.

Tschudi J.J. von 1845. Reptilium conspectum quae in Republica Peruana reperiuntur et pleraque observata vel collecta sunt in itinere. Archiv für Naturgeschichte 11: 150-170.

Uzzell T. 1973. A revision of lizards of the genus Prionodactylus, with a new genus for P. leucostictus and notes on the genus Euspondylus (Sauria, Teiidae). Postilla 159: 1-67.

Zaher H. 1999. Hemipenial morphology of the South American xenodontine snakes with a proposal for a monophyletic Xenodontinae and a reappraisal of colubroid hemipenes. Bulletin of the American Museum of Natural History 240: 1-168.

\section{Appendix}

\section{Additional material examined}

Anadia blakei (1) VENEZUELA: Sucre: Cerro Humo, Península de Paria, EBRG 2746.

Anadia marmorata (2) VENEZUELA: Aragua: Estación Biológica de Rancho Grande, 1100 m, EBRG 3423. Distrito Capital: sector Jerenba Parque Nacional Macarao, $2300 \mathrm{~m}$ (living specimen to be deposited at EBRG).

Anadia escalerae (1) VENEZUELA: Bolívar: La Escalera, 132 km SE Río Cuyuní (= 46 km SE km 88) on the road to Santa Elena de Uairén, EBRG 1998 (holotype).

Euspondylus acutirostris (3) VENEZUELA: Aragua: Carretera El Junquito-Colonia Tovar, a $1.5 \mathrm{~km}$ a la derecha del arco de la Colonia Tovar, 2350 m. MHNLS 17474. Falcón: Sierra de San Luis, cerro Galicia, La Soledad, 1200 m. EBRG 3971. Yaracuy: Pico el Tigre, Parque Nacional Yurubí, $1700 \mathrm{~m}$ (living specimen to be deposited at EBRG).

Manuscript received: 5 August 2011

Manuscript accepted on: 5 September 2011

Published on: 29 September 2011

Topic editor: Rudy Jocqué

In compliance with Article 8.6 of the ICZN, printed versions of all papers are deposited in the libraries of the institutes that are members of the EJT consortium. 